\title{
異型線維性組織球腫
}

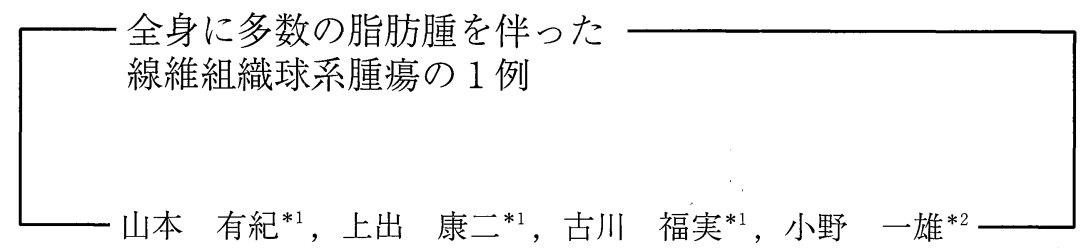

\section{A case of atypical fibroxanthoma associated with generalized multiple lipoma}

\author{
Yuki YAMAMOTO ${ }^{* 1}$, Koji UEDE ${ }^{* 1}$, Fukumi Furukawa ${ }^{* 1}$, Kazuo ONO *2 \\ *1 Department of Dermatology, Wakayama Medical University \\ *2 Division of Pathology, Wakayama Medical University
}

A 62-year-old male had a subcutaneous hard tumor on the left cheek, which had grown gradually to $3.5 \mathrm{~cm}$ in diameter. The tumor invaded into subcutaneous tissue and moderately well-demarcated. Histrogically the neoplastic cells were typically pleomorphic, many spindled, and distributed in fascicles or haphazardly. Atypical mitoses and histiocytoid cells were frequent found. Immunohistochemically, neoplastic cells were positive for vimentin, CD68 and CD74, and negative for $\alpha$ smooth muscle actin, desmin, CD31, CD34 and factor VIII. Atypical fibroxanthoma (AFX) is histologically similar to malignant fibrous histiocytoma (MFH). It was assumed that MFH differs from AFX only by its deeper location and larger size. [Skin Cancer (Japan) $2001 ; 16$ : 192-195]

Key words : Atypical fibroxanthoma, Malignant fibrous histiocytoma, CD74

\section{はじめに}

異型線維黄色腫 (atypical fibroxanthoma 以下 AFX) は，1961 年に Helwig ${ }^{1)} に よ り$ 提唱され た高齢者の日光変性を基盤に真皮に発生した悪 性度の低い線維組織系腫瘍で, 悪性線維組織球 症 (malignant fibrous histiocytoma 以下 $\mathrm{MFH}$ ) とは組織学的に鑑別不能といわれ，一般に腫瘍

${ }^{* 1}$ 和歌山県立医科大学波膚科（主任 古川福実教授）

$* 2$ 和歌山県立医科大学中央検查部病理部門
の深さ，解剖学的部位より鑑別される。しかし 免疫染色で両者を鑑別した論文 ${ }^{2)}$ みられる反 面, 皮下脂肪織に深く浸潤するAFXは転移の可 能性もあり悪性度が低いとはいえないことよ り，両者は同一疾患であると提唱する意見もあ る。今回我々は, AFX と $\mathrm{MFH}$ の診断に苦慮し た症例を経験したので報告する。

\section{症例}

患 者: 62 歳, 男

初診: 1999 年 9 月 17 日 
主 訴：左㚘部の皮下腫瘍

家族歴，既往歴：特記すべき事はない。

現病歴：約 6 力月前に左煩部の皮下腫瘍に気 付き，徐々に増大するため他院受診し；生検の 結果，血管肉腫が疑われ当科へ紹介された。

初診時現症：左煩部に径 $3.5 \times 3.5 \mathrm{~cm}$ 大の無 痛性の下床との可動性のある弾性硬の皮下腫瘍 を認めた（図1）。腫瘍の表面は赤褐色を呈し， 毛細血管の拡張を伴っていた。

また右㚘部対側性に柔らかい無痛性の皮下腫 瘤を触知し, 同様の腫瘤は前胸部 (図 2), 上肢, 背部にも認めた。

検査所見：血液検査，および頸部，胸部，腹 部 CTでは異常を認めなかった。

治 療：再度生検の結果 AFX もしくは $\mathrm{MFH}$ を疑われ, 組織学的精査のため, 腫瘍から $2 \mathrm{~cm}$ 離し骨膜上で一塊に摘出し, 全層植皮にて再建

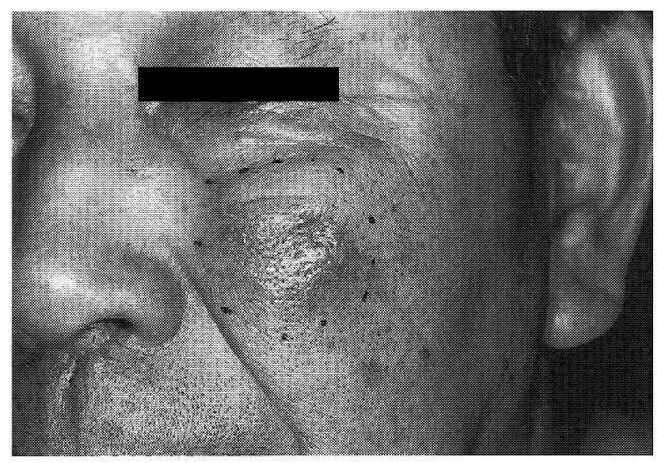

図 1，初診時臨床像

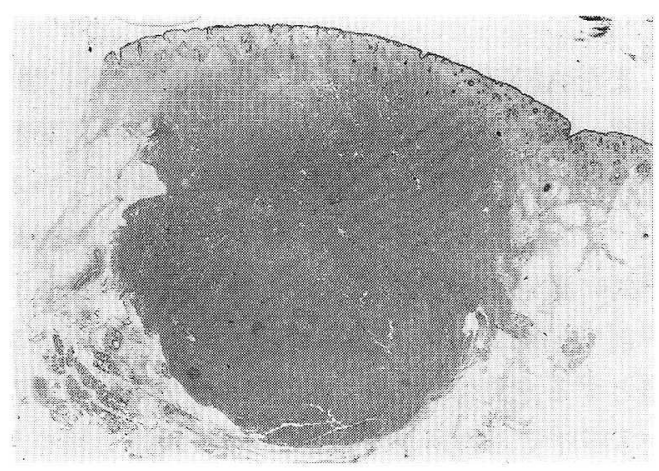

図 3.病理組織像 (H.E. 染色.弱拡大像)
をした。

病理組織学的所見：腫瘍は径 $20 \times 20 \mathrm{~cm}$ 大の 比較的境界明瞭な充実性の腫瘍で, 真皮上層か ら皮下脂肪織にかけて存在した（図 3 )。真皮上 層では日光变性を認め, 比較的異型性の少ない 線維芽細胞様の腫瘍細胞が散在し，下層では大 部分が境界明瞭で皮下脂肪内に限局していた が，一部に境界不明暸に筋層内に浸潤している 部位も認めた（図４）。個々の腫瘍細胞は紡錘型

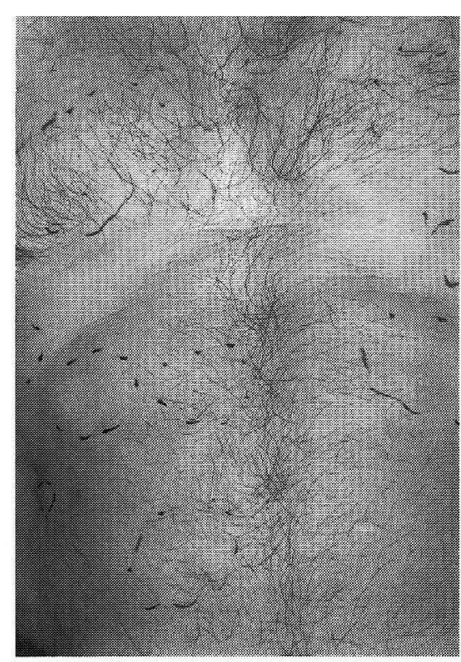

図 2．前胸部の皮下腫瘤

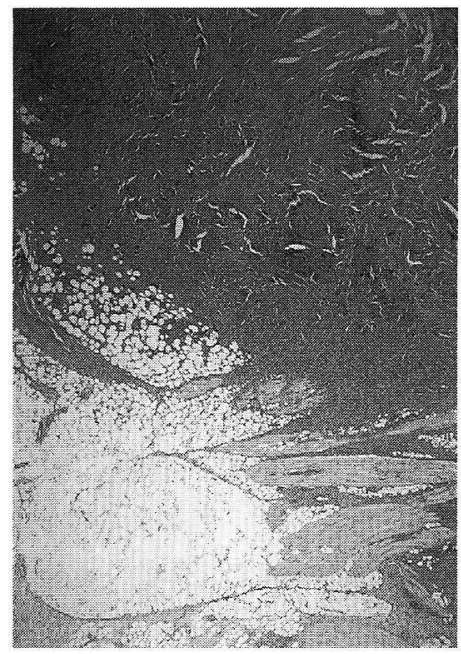

図 4.病理組織像（H.E. 染色.強搪大像） 腫瘍細胞が筋層内に浸潤 


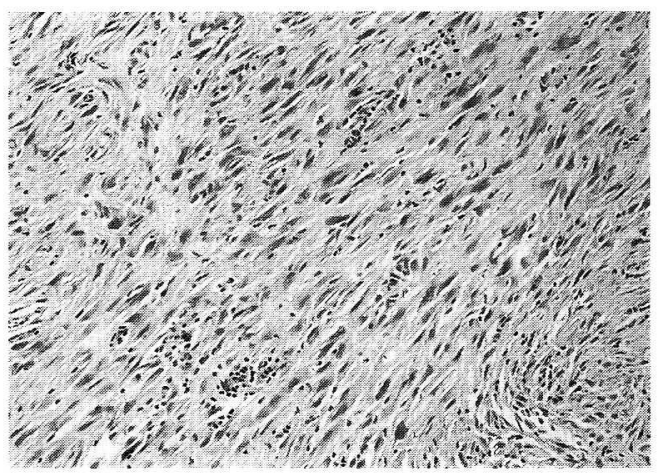

図 5. 線維芽細胞様の腫瘍細胞

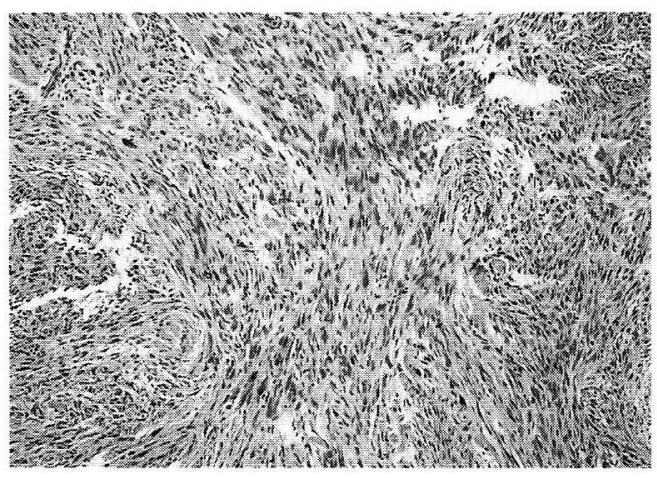

図 7.腫瘍細胞の花むしろ様配列

の異型性の核を持つ線維芽細胞様の細胞 (図 5) と, クロマチンに富む多角形の核を有し比 較的細胞質の豊富な組織球様の細胞が主体で, 一部にクロマチンにそしい大型の核を有する細 胞も認め（図 6), 索状に配列あるいは錯綜し, 不明瞭ながら花むしろ様の配列もみられた（図 7 )。腫瘍内には壞死を認めず, 細胞の異型性は 深部ほど強く, 核分裂像は強拡大 20 視野中 7 個 みられた。また免疫組織学的には，ビメンチン が全体に強く胞体に陽性で, CD68, CD74は一 部陽性, $\alpha$ smooth muscle actin, デスミン, CD31，CD34，第 8 因子，EMA，および $\mathrm{S} 100$ は陰性であった。一方, 右煩部の皮下腫瘍は組 織学的に angiolipomaで, 体幹, 上肢は lipoma であった。

経 過：術後植皮部の㓔痕拘縮のため下眼瞼 の外反を認め, 全層植皮術を施行したが, 術後

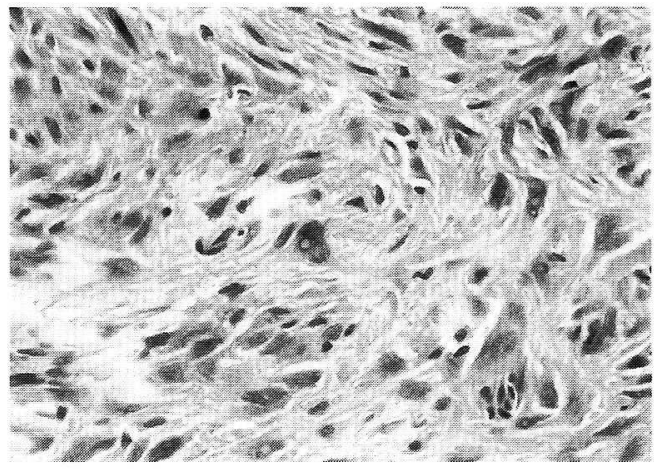

図 6.クロマチンに乏しい大型の核を持つ腫瘍細胞

15 カ月, 腫瘍の再発, 転移は認めていない。

\section{考察}

MFH は軟部悪性腫瘍の中で最も頻度が高く, $50 \sim 70$ 歳男性の四肢や後腹膜に好発する腫瘍 で，深部への浸潤や転移を生じやすく早期に広 範囲切除が必要となる。多くが筋層内などの深 部に生じるが，皮下に生じる場合は表面は正常 皮膚色一暗赤色を呈し, 平滑, 凹凸不整, 潰瘍 形成などの多彩な臨床を呈する硬い隆起性腫瘍 で，多結節状を呈したり，腫瘍周囲に小腫瘤を 伴うこともある。本症は, 線維芽細胞様細胞と 組織球様細胞とを種々の割合で有する未分化で 多形性の肉腫とされているが，その本態や発生 起源などは解明されていないため, 現状では臨 床病理学的所見をもって診断がなされてい る ${ }^{3)}$

また $\mathrm{AFX}^{2)}$ は, 高齢者の日光露出部, 特に鼻, 㚘部, 耳に好発し, 通常は $3 \mathrm{~cm}$ 以下の小結節状 の皮疹で，臨床的には良性腫瘍とされている が，まれに転移する症例もある。 $\mathrm{MFH}$ とは組織 学的に鑑別不能といわれ, 一般に腫瘍の深さ, 解剖学的部位より鑑別されるため $\mathrm{MFH}$ の浅在 型とする意見もある4)。Lazova ら ${ }^{5)}$ は，CD74 が MFH で陽性所見を示し, 同じ組織形態をと るAFXでは陰性であったということから， CD74 は AFX と MFH の鑑別に有用であると報 
告した。CD74は35-kDaの蛋白抗原で, HLA-DR 群の蛋白と同じファミリーに属する分子であ り, B 細胞, 組織球, 胸腺の樹枝状細胞, ReedSternberg 細胞などに表現され，骨髄腫やバー キットリンパ腫などの腫瘍細胞に陽性を示すと いわれている。しかし彼らは AFXでもサイズが 大きい，あるいは深部浸潤性のものでは CD74 が陽性であったとも報告している ${ }^{5)}$ 。

自験例の特徵を以下に述べる。本症例が $\mathrm{MFH}$ と示唆される所見は 1 ) 切片上, 腫瘍面積 の大部分（80９0\%）は皮下脂肪組織内にあり， 脂肪組織内発生の可能性が高い。真皮に発生す るといわれている AXF とは発生起源が異なる 可能性がある。2）腫瘍細胞は CD74 が陽性。 3 ) 真皮発生であっても, 脂肪組織に浸潤する $\mathrm{AFX}$ はFH と考えるべきとする見解もある ${ }^{5)}$ 。 逆に $\mathrm{MFH}$ に否定的な所見としては1） $\mathrm{MFH}$ は, 四肢, 体幹, 後腹膜などの深部軟部組織, 特に大きな骨格筋に発生する腫瘍であり, 顔面 にはまれである。2）MFH にしては，腫瘍径 が小さい。また，通常 MFH は多結節状の肉眼 像を示すが，本症例は単結節状である ${ }^{4)}$ 。

本症例は，高齢者の日光変性を基盤として発 生した低悪性度線維組織球性で, AFX 最も考え られるが, 近年では AFX という概念の存在が再
検討されており, 本症例においても今後, $\mathrm{MFH}$ と同様な長期の経過観察を予定している。脂肪 腫との関連については現在のところ不明であ り，今後の症例の蓄積により結論が出ることを 期待する。

\section{文献}

1) Helwig, E.B. : Atypical fibroxanthoma. Proceedings of 18th Annual Tumor Seminar of San Antonio Society of Pathologists. Tex State J. Med., 59 : 664667, 1963.

2) Glavin, F.L. and Cornwell, M.L.: Atypical fibroxanthoma of the skin metastatic to lung. Am. J. Dermatopathol., 7: 57-63, 1985.

3) Enzinger, F.M. : Soft Tissue Tumors (ed2). St. Louis, MO, Mosby, 1988, p275.

4) Stadler, F.J., Scott, G.A. and Brown, M.D. : Malignant Fibrous Tumors. Semin, Cutan. Med. Surg., $17: 141-52,1998$.

5) Lazova, R., Moynes, R., May, D. and Scott, G. : LN2 (CD74). a marker to distinguish atypical fibroxanthoma from malignant fibrous histiocytoma. Cancer, $79: 2115-2124,1997$.

6) Heintz, P.W. and White, C.R. Jr. : Diagnosis : atypical fibroxanthoma or not? Evaluating spindle cell malignancies on sun damaged skin: a practical approach. Semin. Cutan. Med. Surg., 18 : 78-83, 1999. 